\title{
Profiles of cytokine and chemokine gene expression in human pulmonary epithelial cells induced by human and avian influenza viruses
}

\author{
WY Lam ${ }^{1}$, Apple CM Yeung ${ }^{1}$, Ida MT Chu', Paul KS Chan ${ }^{1,2^{*}}$
}

\begin{abstract}
Influenza pandemic remains a serious threat to human health. In this study, the repertoire of host cellular cytokine and chemokine responses to infections with highly pathogenic avian influenza $\mathrm{H} 5 \mathrm{~N} 1$, low pathogenicity avian influenza H9N2 and seasonal human influenza H1N1 were compared using an in vitro system based on human pulmonary epithelial cells. The results showed that H5N1 was more potent than H9N2 and H1N1 in inducing CXCL-10/IP-10, TNF-alpha and CCL-5/RANTES. The cytokine/chemokine profiles for H9N2, in general, resembled those of H1N1. Of interest, only H1N1, but none of the avian subtypes examined could induce a persistent elevation of the immune-regulatory cytokine - TGF- $\beta 2$. The differential expression of cytokines/chemokines following infection with different influenza viruses could be a key determinant for clinical outcome. The potential of using these cytokines/chemokines as prognostic markers or targets of therapy is worth exploring.
\end{abstract}

\section{Background}

Avian influenza viruses (AIV) are classified into two pathotypes. The highly pathogenic type (HPAIV) causes severe disease with a high mortality rate, whereas the low pathogenic type (LPAIV) causes asymptomatic infection or a mild disease $[1,2]$. Human infection with HPAIV H5N1 was first detected in Hong Kong in 1997 [3-5]. As at July 2009, more than 400 human infections have been reported to the World health Organization (WHO), and with an average case fatality rate of greater than $60 \%$ (WHO 2010). Hypercytokinaemia was consistently reported from patients with fatal H5N1 infection [4,6-9].

Influenza viruses of the $\mathrm{H} 9$ subtype have been widely circulated in the world since their first detection from turkeys in Wisconsin in 1966 [10]. H9N2 viruses had caused disease outbreaks in chicken, ducks and pigs in many parts of the world including China, Germany, Hong Kong, Indonesia, Iran, Ireland, Israel, Italy, Jordan, Pakistan, Saudi Arabia, South Africa, South Korea, UAE, and USA in recent years [11-18]. In 1999 and 2003, selflimiting mild human infections with LPAIV H9N2

\footnotetext{
* Correspondence: paulkschan@cuhk.edu.hk

'Department of Microbiology, The Chinese University of Hong Kong, New Territories, Hong Kong Special Administration Region, People's Republic of China

Full list of author information is available at the end of the article
}

viruses were recorded in Hong Kong [19]. Some avian $\mathrm{H} 9$ viruses have acquired receptor binding characteristics typical of human strains, which may increase the potential for reassortment in both human and swine respiratory tracts [20-22].

The respiratory epithelial cells are the primary targets for HPAIV and LPAIV infections [23-25]. In response to HPAIV and LPAIV, these cells are likely to play a critical role in inflammatory response, and in the initiation of innate and subsequently adaptive immune responses [3,25-29]. Recently, it has been reported that HPAIV H5N1 infection of epithelial cells induce the expression of several proinflammatory cytokines and chemokines both in vitro and in vivo, which could be linked to the consequence of fatal hypercytokinemia [8,30-32].

The biological basis accounting for the difference in disease severity among different avian influenza virus infections in humans remains unknown. In this study, we compared the effect of different avian and human influenza subtypes on the induction of cytokine and chemokine expression using an in vitro model.

\section{Results}

Influenza virus replication

A similar rate of change in viral RNA copy numbers following the inoculation of human and avian viruses was 


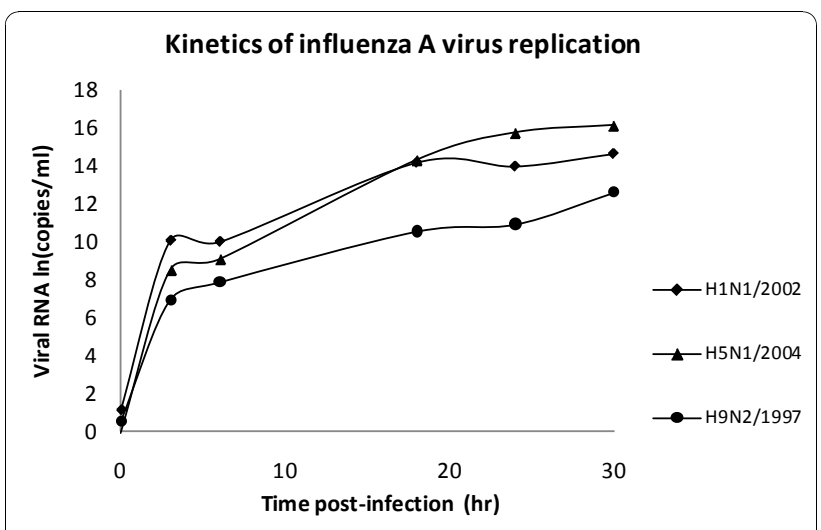

Figure 1 Kinetics of replication of different subtypes of influenza A virus in $\mathbf{N C l}-\mathrm{H} 292$ cells. $\mathrm{NCl}-\mathrm{H} 292$ cells were infected with different influenza virus subtypes: $\mathrm{H} 1$ - H1N1/2002, H5 - H5N1/ 2004, and H9 - H9N2/1997 with an m.o.i. of 1. Plasmid copy number expressed in natural logarithm (In).

observed for H1N1/2002 and H5N1/2004 indicating that these viruses replicated with a similar kinetic in the cell culture system (Figure 1). H9N2/1997 virus was found to replicate at a lower rate than the other two subtypes. All the virus subtypes reached the plateau level within 6 hours post-infection, and then increased steadily (Figure 1).

\section{Cytokine/chemokine mRNA expression during the early phase of viral infection}

The quantitative real-time RT-PCR results showed that during the early phase of infection (i.e. 3 and 6 hours post-infection), there was an induction of pro-inflammatory cytokines/chemokines. At 3 hours post-H5N1/ 2004 infection, there were 2-5 folds increase in the expression of TNF- $\alpha$ and CCL-5/RANTES. At 6 hours post-H5N1/2004 infection, there were marked increase in the expression of CXCL-10/IP-10 and CCL-5/ RANTES (60-120 folds); while there were only relatively minor increase in IL-6 and IL-8 expression (2-10 folds) (Figure 2, Table 1).

Similarly for H9N2/1997 infection, there was 5-25 folds increase in the transcription of CCL-5/RANTES, TNF- $\alpha$, and CXCL-10/IP-10 mRNA at 3 hours postinfection. At 6 hours post-infection, the level of previously elevated cytokines/chemokines still remained at several folds of induction. In contrast to the prominent induction of cytokines/chemokines observed for avian subtypes, the induction by human subtype H1N1 was always below 10 folds during the early phase of infection.

In summary, up-regulation of mRNA for TNF- $\alpha$, CCL-5/RANTES, and CXCL-10/IP-10 was found to be more prominent during the early phase of infection with $\mathrm{H} 5 \mathrm{~N} 1 / 2004$ and H9N2/1997 viruses than those induced by $\mathrm{H} 1 \mathrm{~N} 1 / 2002$ virus.

\section{Cytokine/chemokine mRNA expression during the late phase of infection}

At the late phase of $\mathrm{H} 5 \mathrm{~N} 1$ infection, more intense induction of cytokine/chemokine expression was observed. At 18 hours post-infection, IL-6, CCL-5/ RANTES and CXCL-10/IP-10 were highly expressed (12 to $>1000$ folds) in $\mathrm{H} 5 \mathrm{~N} 1 / 2004$ infection. Meanwhile, TNF- $\alpha$ and IL- 8 were expressed at $>10$ folds in H5N1/ 2004 infection. At 24 hours post-infection, the previously elevated cytokines/chemokines were still remained at high levels. As for $\mathrm{H} 5 \mathrm{~N} 1 / 2004$ infection, CCL-5/RANTES and CXCL-10/IP-10 were found to be induced to $>1000$ folds; whereas TNF- $\alpha$ and IL- 8 were expressed at 200-300 folds. (Figure 2, Table 2).

Similarly, at 18 hours post-H9N2/1997 infection, CCL5/RANTES mRNA expression was found to be induced by nearly 1000 folds; while CXCL-10/IP-10, IL-6, and IL-8 were found to be up-regulated by $16-116$ folds.

Although no significant cytokine/chemokine induction was observed during the early phase of H1N1 infection; IP-10/CXCL-10, TNF- $\alpha$, TGF- $\beta 2$, CCL-5/RANTES, IL8 , and IL- 6 were found to be 4-450 folds induced during the late phase of infection (Figure 2, Table 2).

In summary, at the late phase of infection (i.e. 18 and 24 hours post-infection), TNF- $\alpha$, IL-6, IL-8, CCL-5/ RANTES and CXCL-10/IP-10 mRNA remained at high levels for $\mathrm{H} 5 \mathrm{~N} 1 / 2004$ and $\mathrm{H} 9 \mathrm{~N} 2 / 1997$; which were in contrast to those observed for $\mathrm{H} 1 \mathrm{~N} 1 / 2002$ (Figure 2, Table 2). The up-regulation of these mRNA was more prominent in $\mathrm{H} 5 \mathrm{~N} 1 / 2004$ infected cells, and the maximal up-regulation of these mRNA in H5N1/2004 infection occurred at 24 hours post-infection (Figure 2). Overall, the intensity of cytokine/chemokine mRNA induction in human $\mathrm{H} 1 \mathrm{~N} 1 / 2002$ was much lower than that observed in avian $\mathrm{H} 5 \mathrm{~N} 1$ and $\mathrm{H} 9 \mathrm{~N} 2$. Interestingly, the TGF- $\beta 2$ mRNA was found to be up-regulated for H1N1/2002 and H9N2/1997, but not for H5N1/2004 (Figure 2, Table 2).

\section{Cytokine/chemokine protein profiles following infection}

To verify whether changes at the mRNA level were translated to protein level, the protein concentrations of cytokines/chemokines in cell culture supernatants were measured (Figure 3, Table 3). The results showed that the epithelial cells secreted high amounts of IL-6, IL-8, CXCL-10/IP-10, and CCL-5/RANTES in response to influenza virus infections. In H5N1/2004 and H9N2/ 1997 infections, IL- 6 was induced to a high level at 24 hours post-infection ( 4 and 3 folds, respectively); while H1N1/2002 induced a high level of IL-6 (about 8 folds) at 18 hours post-infection. The expression profile for IL-8 and CXCL-10/IP-10 was similar to IL-6. In H5N1/ 2004 infection, induction of cytokine/chemokine was prominent at the late phase ( 24 hours post-infection). 


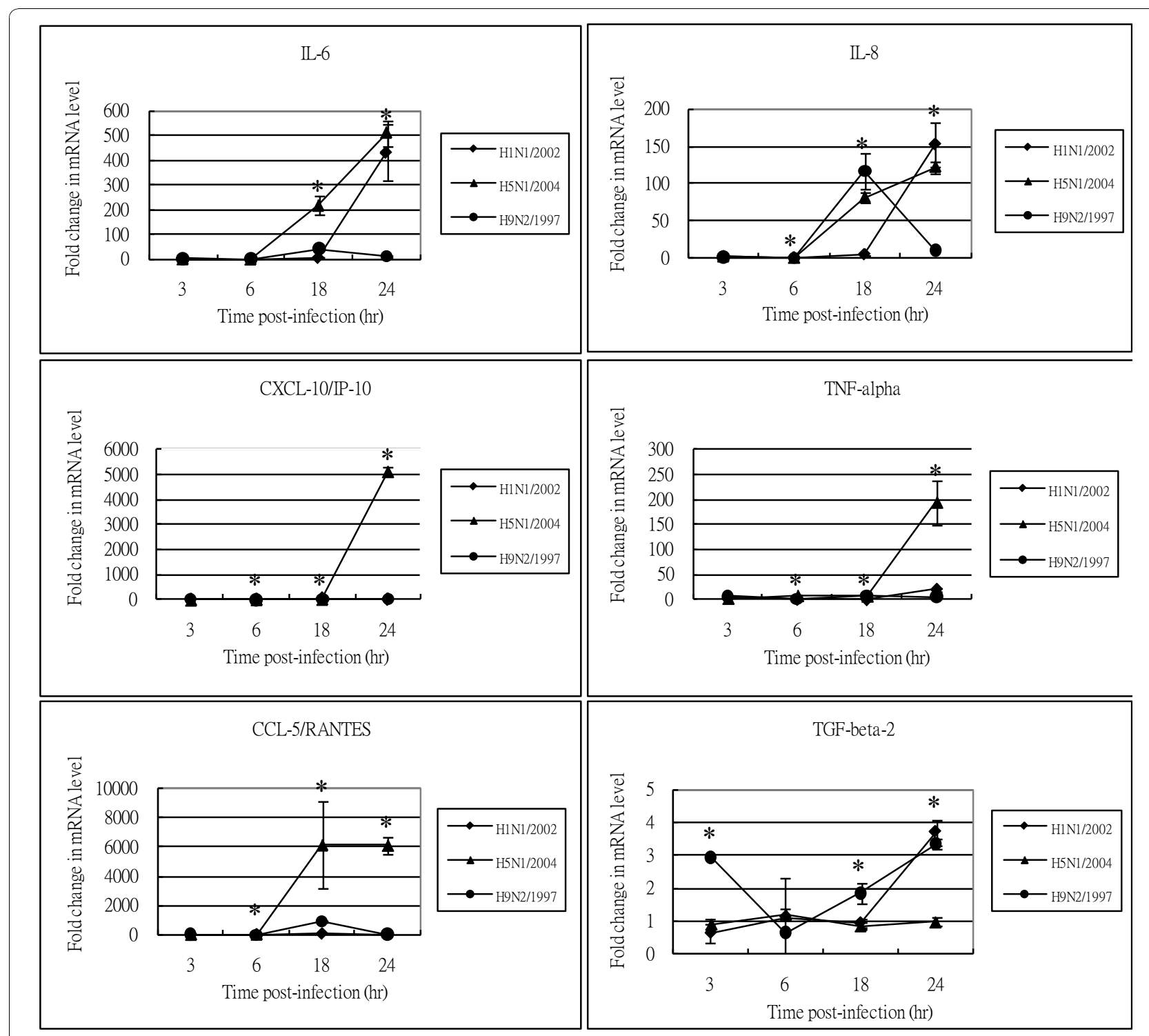

Figure 2 Cytokine and chemokine mRNA levels at various time points post-infection. $\mathrm{NCl}-\mathrm{H} 292$ cells were infected with influenza A virus subtypes: H1N1/2002, H5N1/2004, and H9N2/1997 viruses at m.o.i. = 1. Real-time PCR were used to quantitify the mRNA levels and fold-changes were calculated by $\Delta \Delta^{C T}$ method as compared with non-infection cell control and using endogeneous actin mRNA level for normalization. Each point on the graph represents the mean fold change in gene expression relative to $\mathrm{NI}$ - non-infected cells level $\pm \mathrm{SE}\left(\mathrm{p}^{*}<0.05\right)$.

H5N1/2004 showed 150 folds of induction for CXCL10/IP-10. IL-6 and CXCL-10/IP-10 were induced in H9N2/1997 infections; but at relatively lower foldchanges than those of H5N1 throughout the time course examined (Figure 3, Table 3). The highest level of induction (36 folds) for CCL-5/RANTES was observed at the late phase of $\mathrm{H} 5 \mathrm{~N} 1 / 2004$ infection (18-24 hours) (Figure 3, Table 3). In general, $\mathrm{H} 5 \mathrm{~N} 1 / 2004$ showed a higher capacity in inducing CXCL-10/IP-10 and CCL-5/ RANTES as compared with that of H1N1 and H9N2;

Table 1 Cytokine/chemokine mRNA expression during the early phase of viral infection

\begin{tabular}{lllllll}
\hline Fold-changes & TNF- $\boldsymbol{\alpha}$ & CCL-5/RANTES & CXCL-10/IP-10 & IL-6 & IL-8 & TGF- $\mathbf{3 2}$ \\
\hline H5N1/2004 & $2-5$ & $2-5$ & $60-120$ & $2-10$ & $2-10$ & 1 \\
\hline H9N2/1997 & $5-25$ & $5-25$ & $5-25$ & 5 & 5 & 3 \\
\hline H1N1/2002 & $<10$ & $<10$ & $<10$ & $<10$ & $<10$ & $<10$ \\
\hline
\end{tabular}


Table 2 Cytokine/chemokine mRNA expression during the late phase of viral infection

\begin{tabular}{lllllll}
\hline Fold-changes & TNF- $\boldsymbol{\alpha}$ & CCL-5/RANTES & CXCL-10/IP-10 & IL-6 & IL-8 & TGF- $\mathbf{\beta 2}$ \\
\hline H5N1/2004 & $200-300$ & $12->1000$ & $12->1000$ & $12->1000$ & $200-300$ & 1 \\
\hline H9N2/1997 & $5-25$ & 1000 & $16-116$ & $16-116$ & $16-116$ & 3 \\
\hline H1N1/2002 & $4-450$ & $4-450$ & $4-450$ & $4-450$ & $4-450$ & $4-450$ \\
\hline
\end{tabular}

and the effects were more prominent at the late phase of infection, particularly at 24 hours post-infection. Also, the cytokine/chemokine protein levels correlated with the corresponding mRNA transcription levels for all the subtypes except that there were some deviations at the late phase of $\mathrm{H} 1 \mathrm{~N} 1$ infection.

TNF- $\alpha$ was induced by all subtypes beginning at the early phase of infection. A 3 -fold increase in TNF- $\alpha$ secretion in late $\mathrm{H} 5 \mathrm{~N} 1 / 2004$ infection was also observed, and these results correlated with the TNF- $\alpha$ mRNA levels.

No induction in TGF- $\beta 2$ level for H5N1/2004 was observed throughout the time course examined. The TGF- $\beta 2$ level of H9N2/1997 only showed a transient elevation at 6 hours post-infection. In contrast, the elevation of TGF- $\beta 2$ level of H1N1/2002 was sustained and increased with time reaching $2-3$ folds at 18 and 24 hours post-infection (Figure 3, Table 3).

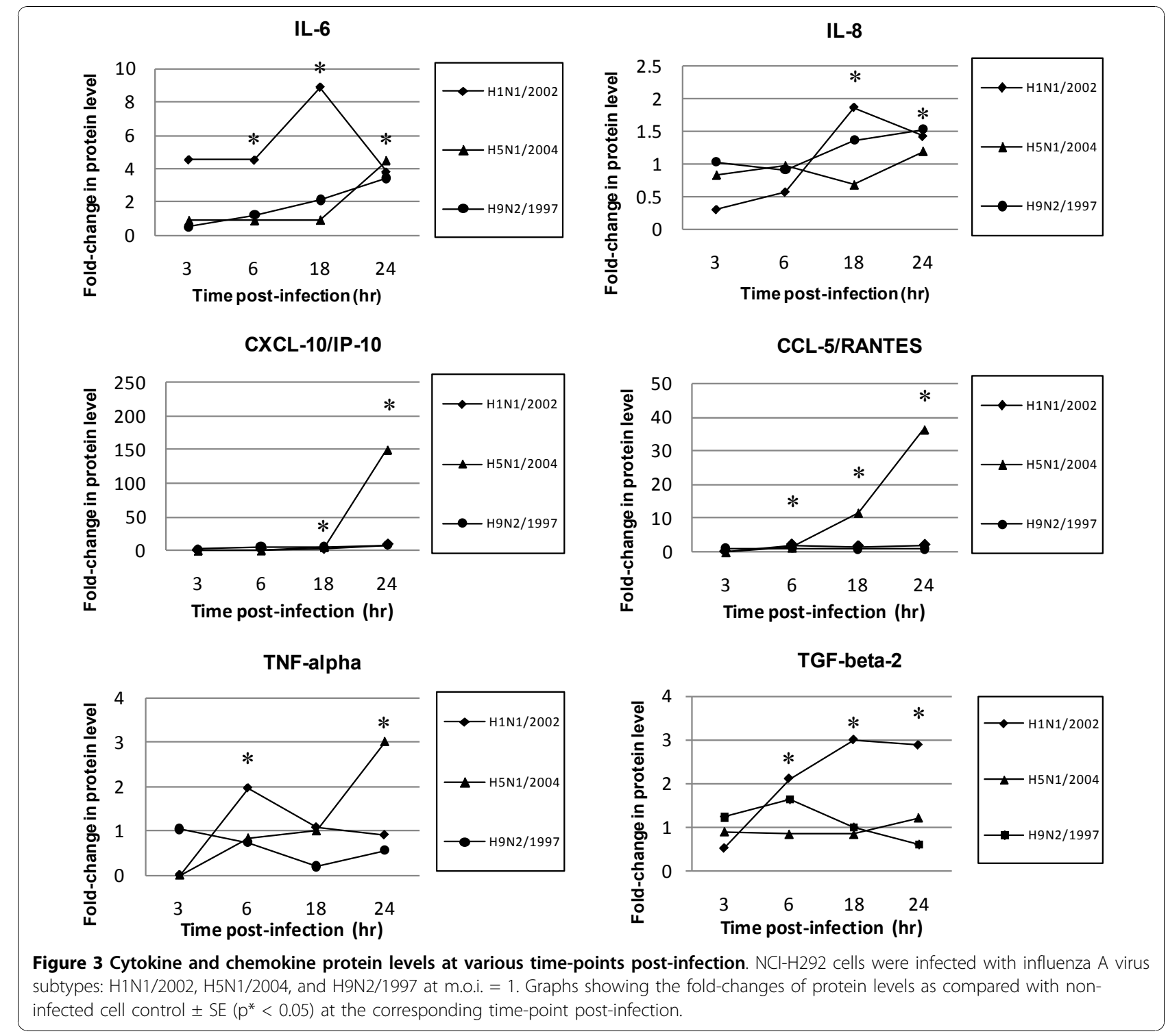


Table 3 Cytokine/chemokine protein profiles following viral infection

\begin{tabular}{lllllll}
\hline Fold-changes & TNF- $\boldsymbol{\alpha}$ & CCL-5/RANTES & CXCL-10/IP-10 & IL-6 & IL-8 & TGF- 32 \\
\hline H5N1/2004 & 3 & 36 & 150 & 4 & 1.3 & 1 \\
\hline H9N2/1997 & 1.2 & 3 & 12 & 3 & 1.6 & 1.5 \\
\hline H1N1/2002 & 1 & 2 & 10 & 8 & 1.4 & 3 \\
\hline
\end{tabular}

\section{Discussion}

Lung epithelial cells are the key target of influenza viruses $[33,34]$. However, to date, most studies on influenza virus-induced inflammatory cytokines have been based on macrophages and monocytes infected in vitro or in vivo [35-37]. The mechanism concerning bronchial infiltration of inflammatory cells, particularly lymphocytes and eosinophils, and the subsequent hyperresponsiveness of the bronchial wall induced by viral infection remains unclear [38].

Due to the fact that HPAIV and LPAIV infection can cause a different degree of immune response, we hypothesized that the highly pathogenic properties of HPAIV may be caused by two determinants: firstly, the viruses have the ability to over-induce proinflammatory cytokines, for example, excessive activation of the pathogen detecting receptors, which may result in excessive secondary cytokine/chemokine response. Secondly, the viruses may directly or indirectly interfere with the balance of cytokine/chemokine production. For example, the feedback mechanism of cytokine/chemokine biosynthesis may be interrupted by the viral components.

Cytokines and chemokines generally function in an autocrine (on the producing cell itself) or paracrine (on nearby cells) manner. Cytokines released following infection can be classified broadly into "early" and "late" cytokines. In this study, the transcription levels of 6 cytokines/chemokines were delineated over the 24-hour period following virus inoculation. Recently, it has been found that the inflammatory response is played out over time in a reproducible and organized way after an initiating stimulus. It had been suggested that genes activated in mouse fibroblasts in response to the cytokine TNF- $\alpha$ could be categorized into roughly three groups, each with different induction kinetics [39]. These observations are in line with our findings that the cytokine/ chemokine response profile varied with the time-course of infection. Our results showed that at the early phase of avian influenza virus infection, the transcription of TNF- $\alpha$ and IL- 6 was induced. At the late phase of infection; induction of IL-8, CCL-5/RANTES, and CXCL-10/ IP-10 occurred.

Although TNF- $\alpha$ was first noted for its role in killing tumor cells [40], it also has pleiotropic functions including inflammatory response and host resistance to pathogens $[34,41]$. TNF- $\alpha$ may activate nuclear factor-kB
(NF-kB) by inducing the phosphorylation and degradation of inhibitory factor- $\mathrm{kB}(\mathrm{IkB})$ and leads to the translocation of NF-kB to the nucleus where it can bind to specific-binding sites of the relevant promoters. It has been reported that NF-kB regulates many kinds of genes and plays a crucial role in inflammatory diseases $[39,42]$. Subsequent binding of NF-kB to the CCL-5/RANTES promoter has also been reported $[43,44]$. In line with this, we also observed an induction of CCL-5/RANTES in avian influenza infection, which may then attract monocytes, eosinophils, basophils, and CD4+ T cells [45]. CCL-5/RANTES production from bronchial epithelial cells contributes to infiltration of inflammatory cells in the airway during viral infection. The other chemokine, CXCL-10/IP-10, found upregulated by avian influenza viruses is a macrophage chemo-attractant that mediates inflammatory response by further recruitment of circulating leukocytes into the inflamed tissues [25]. In addition, IL- 8 is also a potent chemo-attractant and stimulus of neutrophils. It plays a pivotal role in inflammatory diseases. It is also well known that IL-6 plays an important role in the stimulation of B lymphocytes for antibody production. TNF- $\alpha$ together with IL- 6 may boost proliferation and differentiation of $\mathrm{B}$ cells, and proliferation of T cells. As a result, all these TNF- $\alpha$ activated mediators could contribute to the infiltration of inflammatory cells into the influenza infected respiratory tract.

Our results showed that $\mathrm{H} 5 \mathrm{~N} 1$ was a potent inducer of CXCL-10/IP-10 and CCL-5/RANTES. The induction of these cytokines/chemokines might be initially achieved by a trace amount of TNF- $\alpha$ secretion as detected during the initial phase of infection. Therefore, initial TNF- $\alpha$ secretion might be critical to account for the high pathogenicity of $\mathrm{H} 5 \mathrm{~N} 1$ infection.

Although seasonal influenza A/H3N2 has been more prevalent over the last 10 years, and there is evidence that it is more virulent in humans [46-48], we chose $\mathrm{H} 1 \mathrm{~N} 1$ because of its lower pathogenicity and therefore a better reference for comparison with the highly pathogenic $\mathrm{H} 5 \mathrm{~N} 1$ virus.

Another important aspect of balancing cytokine/chemokine production is the role of the anti-inflammatory mediators. Accordingly, the secretion of a well-known anti-inflammatory cytokine/chemokine, TGF- $\beta 2$, was measured in this study. Our data showed that H1N1 
induced the highest transcription of TGF- $\beta 2$ mRNA, and was the only subtype that could induce a sustained increase in TGF- $\beta 2$ at protein level. Since TGF- $\beta$ can act as both an immunosuppressive agent and a potent proinflammatory molecule through its ability to attract and regulate inflammatory molecules, it plays a vital role in $\mathrm{T}$-cell inhibition. Furthermore, it has been reported that TGF- $\beta 2$ inhibits Th1 cytokine-mediated induction of CCL-5/RANTES, CCL-3/MIP-1 $\alpha$, CCL-4/MIP-1 $\beta$, CCL-9/MIP-1 $\gamma$, CXCL-2/MIP-2, CXCL-10/IP-10, and CCL-2/MCP-1 [49]. It has also been found that in real bronchial environments, TGF- $\beta$ mediates cross-talk between alveolar macrophages and epithelial cells [50]. We therefore speculate that, inside the lungs, the activated inflammatory cascade launches a quick antimicrobial reaction and directs adaptive immunity to mount a protective response. The pro-inflammatory response is tightly controlled by mediators, such as TGF- $\beta$, to protect the easily damageable lung tissue from destructive side effects associated with virus induced inflammation. Our speculation coincides with other studies which demonstrated that highly pathogenic $\mathrm{H} 5 \mathrm{~N} 1$ virus infection in mice model could cause a down-regulation of TGF- $\beta$ secretion which resulted in more severe and widespread lesions [51]. These may also account for the difference in pathogenicity of different AIV strains [52,53].

Recently, a concept of organ-specific and graded immune responses was proposed by Eyal Raz [54]. According to this concept, each organ senses infectious dangers in a specific way, and the organ-specific physiology modulates and instructs the local immune response. It has been reported that there is a unique regulatory mechanism of toll-like receptor (TLR) activation pathways that is intrinsic to the lungs. Bronchial epithelial cells modulate the activation of monocytes, macrophages, dendritic cells (DC), and T lymphocytes; thus contributing to the generation of a specific bronchial homeostatic microenvironment that affects the way in which the body copes with the viruses. This homeostatic "circuit" can inhibit excessive inflammatory response in lung tissues [55]. Therefore, the exact regulatory role of this cytokine - TGF- $\beta 2$, and its association with TLR activation in the initiation, progression, and resolution of immune response during infection with influenza viruses with different pathogenicity is worthy for further study.

\section{Conclusion}

There are qualitative and quantitative differences in the profiles of cytokines/chemokines induced by influenza viruses of different pathogenicity. H5N1 was a more potent inducer of inflammatory cytokines/chemokines; particularly TNF- $\alpha$, CXCL-10/IP-10, and CCL-5/
RANTES in lung epithelial cells. In contrast, H1N1 showed more potent induction of the anti-inflammatory cytokine - TGF- $\beta 2$.

\section{Materials and methods}

Virus isolates

The influenza A H5N1 virus (A/Thai/KAN1/2004) (H5N1/2004) was isolated from a patient with fatal infection in Thailand in 2004. The H9N2 isolate (A/ Duck/Hong Kong/Y280/1997) (H9N2/1997) was collected in Hong Kong and was closely related to those found from human H9 infections. These isolates represented avian influenza of high and low pathogenicity. To serve as a comparison, a human H1N1 strain isolated in 2002 - (A/HongKong/CUHK-13003/2002) (H1N1/2002) was included.

\section{Cell cultures}

The bronchial epithelial cells, NCI-H292 (ATCC, CRL1848, Rockville, MD, USA), derived from human lung mucoepidermoid carcinoma were grown as monolayers in RPMI-1640 medium (Invitrogen, Carlsbad, CA) supplemented with $10 \%$ fetal bovine serum (FBS), $100 \mathrm{U} / \mathrm{ml}$ penicillin and $100 \mu \mathrm{g} / \mathrm{ml}$ streptomycin (all from Gibco, Life Technology, Rockville, Md., USA) at $37^{\circ} \mathrm{C}$ in a $5 \%$ $\mathrm{CO}_{2}$ incubator. Mandin-Darby canine kidney (MDCK) cells were used for growing stocks of influenza virus isolates. MDCK cells were grown and maintained in Eagles Minimal Essential Media (MEM) containing 2\% FBS, $100 \mathrm{U} / \mathrm{ml}$ penicillin and $100 \mu \mathrm{g} / \mathrm{ml}$ streptomycin (all from Gibco, Life Technology).

\section{Infection of cell culture with influenza A viruses}

NCI-H292 cells were grown to confluence in sterile T75 tissue culture flasks for the inoculation of virus isolate at a multiplicity of infection (m.o.i.) of one. After 1 hour of adsorption, the virus was removed and $2 \mathrm{ml}$ of fresh RPMI-1640 media with $2 \% \mathrm{FBS}, 100 \mathrm{U} / \mathrm{ml}$ penicillin, $100 \mu \mathrm{g} / \mathrm{ml}$ streptomycin and $1 \mu \mathrm{g} / \mathrm{ml} \mathrm{L-1-tosylamido-2-}$ phenylethyl chloromethyl ketone (TPCK)-treated trypsin (all from Gibco, Life Technology) was added, and incubated at $37^{\circ} \mathrm{C}$ in $5 \% \mathrm{CO}_{2}$ humidified air.

\section{Harvest of host cell RNA}

The infected cell cultures and the non-infected controls were harvested at 3, 6, 18 and 24 hours after virus inoculation. Total RNA was extracted from the cell lysate using TRIzol-total RNA extraction kit (Invitrogen) according to the manufacturer's procedures. The extracted RNA was eluted in $30 \mu \mathrm{l}$ of nuclease-free water, and stored in aliquots at $-80^{\circ} \mathrm{C}$ until used. In order to avoid contamination with genomic DNA, the extracted preparation was treated with DNA-Free DNase (Invitrogen) according to the manufacturer's 
Table 4 Primers used in real-time PCR assays

\begin{tabular}{|c|c|c|}
\hline Amplification target & Forward primer $\left(5^{\prime}-3^{\prime}\right)$ & Reverse primer $\left(5^{\prime}-3^{\prime}\right)$ \\
\hline CCL-5/RANTES & CCCCATATTCCTCGGACACCACA & GTTGGCACACACTTGGCGGTTC \\
\hline CXCL-10/IP-10 & TCGAAGGCCATCAAGAATTT & GCTCCCCTCTGGTITTAAGG \\
\hline IL-6 & ATTCTGCGCAGCTTTAAGGA & GAGGTGCCCATGCTACATTT \\
\hline IL-8 & TGTGCCTTGGTTTCTCCTTI & GCTTCCACATGTCCTCACAA \\
\hline TGF-beta-2 & CCAAAGGGTACAATGCCAAC & TAAGCTCAGGACCCTGCTGT \\
\hline TNF-alpha & CCTGGGATTCAGGAATGTGT & AGGCCCCAGTTTGAATTCTT \\
\hline Beta-actin & GCACGGCATCGTCACCAACT & CATCTTCTCGCGGTGGCCT \\
\hline
\end{tabular}

Primers for cytokine/chemokine detection and primers for actin detection.

instructions. The quality of RNA in the extracted preparation was analyzed by measuring optical density at 260/280 nm with the NanoDrop ND-1000 spectrophotometer (NanoDrop Technologies).

\section{Quantitation of viral replication}

The cDNA was synthesized from previously prepared mRNA with poly(dT) primers and SuperScript III reverse transcriptase (Invitrogen). Quantitative Taqman real-time PCR assay was used to measure the level virus produced in cell culture supernatant. Specific primers amplifying the conserved region of the $\mathrm{M}$ gene of influenza A viruses were used, and quantitative real-time PCR analysis was performed with an ABI PRISM 7700 sequence detection system (Applied Biosystems, Foster City, CA). Preparations with known copy numbers of plasmids cloned with the $M$ gene were used for standard curve construction. The $\beta$-actin gene was used as an endogenous control for normalization [56].

\section{Cytokine/chemokine mRNA expression profile}

Total RNA extracted from cell cultures was reversely transcripted to cDNA using the poly $(\mathrm{dT})$ primers and Superscript III reverse transcriptase (Invitrogen), and quantified by real-time PCR. The sense and antisense primers used in real-time PCR for measuring the cytokines/chemokines (CCL-5/RANTES, CXCL-10/IP-10, IL-6, IL-8, TNF- $\alpha$, TGF- $\beta 2$ ) are listed in Table 4. The real-time PCR reactions were performed in triplicate using the SYBER Green PCR Master Mix (Applied Biosystems). The PCR conditions were $95{ }^{\circ} \mathrm{C}$ for $5 \mathrm{~min}$, followed by 50 cycles of $95{ }^{\circ} \mathrm{C}$ for $30 \mathrm{sec}, 55^{\circ} \mathrm{C}$ for $30 \mathrm{sec}$, and $72{ }^{\circ} \mathrm{C}$ for $30 \mathrm{sec}$. The expression of $\beta$-actin gene was also quantified in a similar way for normalization. The comparative delta-delta $\mathrm{C}_{\mathrm{T}}$ method was used to analyze the results with the expression level of the respective gene at the corresponding time point in noninfected cells regarded as one $[57,58]$.

\section{Quantification of cytokine/chemokine protein expression}

Cell culture medium supernatant was collected at 0,3 , 6,18 , and 24 hours post-infection for the analysis of cytokine/chemokine expression. TNF- $\alpha$, IL-6, IL-8, CXCL-10/IP-10, and CCL-5/RANTES were measured by the Cytometric Bead Array (CBA) Soluble Protein Flex Set system (BD ${ }^{\mathrm{m}}$, San Jose, CA) using the BD FACSCalibur Flow Cytometer System (BD Biosciences) according to the manufacturer's instructions. The biologically active form of TGF- $\beta 2$ was measured by enzyme-linked immunosorbent assay (Emax ${ }^{\ominus}$ ImmunoAssay System, Promega, Madison, WI, USA) because a CBA system for this cytokine was not available.

\section{Acknowledgements}

This study was supported by the Research Fund for the Control of Infectious Diseases, Food and Health Bureau, Hong Kong Special Administrative Region (reference no.: 06060112). We thank Prof. Pilaipan Puthavathana for provision of A/Thailand/1(KAN-1)/2004(H5N1) isolate; and Prof. Malik Peiris for provision of A/Duck/Hong Kong/Y280/1997 (H9N2) isolate.

\section{Author details}

'Department of Microbiology, The Chinese University of Hong Kong, New Territories, Hong Kong Special Administration Region, People's Republic of China. ${ }^{2}$ Stanley Ho Centre for Emerging Infectious Diseases, The Chinese University of Hong Kong, New Territories, Hong Kong Special Administration Region, People's Republic of China.

\section{Authors' contributions}

ACMY performed RT-PCR assays, flow-cytometry assays and IMTC participated in virus culture and virus isolation. WYL was responsible for experimental design, analyses and drafting of the manuscript. PKSC was responsible for design and supervision of the study. All authors read and approved the final manuscript.

\section{Competing interests}

The authors declare that they have no competing interests.

Received: 30 August 2010 Accepted: 26 November 2010 Published: 26 November 2010

\section{References}

1. WHO: Manual on Animal Influenza Diagnosis and Surveillance Geneva: WHO; 2004, 62-63.

2. Maines TR, Szretter KJ, Perrone L, Belser JA, Bright RA, Zeng H, Tumpey TM, Katz JM: Pathogenesis of emerging avian influenza viruses in mammals and the host innate immune response. Immunol Rev 2008, 225:68-84.

3. Yuen KY, Chan PK, Peiris M, Tsang DN, Que TL, Shortridge KF, Cheung PT, To WK, Ho ET, et al: Clinical features and rapid viral diagnosis of human disease associated with avian influenza A H5N1 virus. Lancet 1998, 351:467-471.

4. To KF, Chan PK, Chan KF, Lee WK, Lam WY, Wong KF, Tang NL, Tsang DN, Sung RY, et al: Pathology of fatal human infection associated with avian influenza A H5N1 virus. J Med Virol 2001, 63:242-246. 
5. Chan PK: Outbreak of avian influenza $A(\mathrm{H} 5 \mathrm{~N} 1)$ virus infection in Hong Kong in 1997. Clin Infect Dis 2002, 34(Suppl 2):S58-S64.

6. Peiris JS, Yu WC, Leung CW, Cheung CY, Ng WF, Nicholls JM, Ng TK Chan KH, Lai ST, et al: Re-emergence of fatal human influenza A subtype H5N1 disease. Lancet 2004, 363:617-619.

7. de Jong MD, Hien TT: Avian influenza A (H5N1). J Clin Virol 2006, 35:2-13.

8. de Jong MD, Simmons CP, Thanh TT, Hien VM, Smith GJ, Chau TN, Hoang DM, Chau NV, Khanh TH, et al: Fatal outcome of human influenza A (H5N1) is associated with high viral load and hypercytokinemia. Nat Med 2006, 12:1203-1207.

9. de Jong MD: H5N1 transmission and disease: observations from the frontlines. Pediatr Infect Dis J 2008, 27:S54-S56

10. Homme PJ, Easterday BC, Anderson DP: Avian influenza virus infections. II. Experimental epizootiology of influenza A-turkey-Wisconsin-1966 virus in turkeys. Avian Dis 1970, 14:240-247.

11. Shortridge KF: Avian influenza A viruses of southern China and Hong Kong: ecological aspects and implications for man. Bull World Health Organ 1982, 60:129-135.

12. Alexander DJ: A review of avian influenza in different bird species. Vet Microbiol 2000, 74:3-13.

13. Ninomiya A, Takada A, Okazaki K, Shortridge KF, Kida H: Seroepidemiological evidence of avian $\mathrm{H} 4, \mathrm{H} 5$, and $\mathrm{H} 9$ influenza A virus transmission to pigs in southeastern China. Vet Microbiol 2002, 88:107-114.

14. Butt KM, Smith GJ, Chen H, Zhang LJ, Leung YH, Xu KM, Lim W, Webster RG, Yuen KY, et al: Human infection with an avian H9N2 influenza A virus in Hong Kong in 2003. J Clin Microbiol 2005, 43:5760-5767.

15. Lee SY, Kang EJ, Hur GY, Jung KH, Jung HC, Lee SY, Kim JH, Shin C, In KH, et al: Peroxisome proliferator-activated receptor-gamma inhibits cigarette smoke solution-induced mucin production in human airway epithelial (NCl-H292) cells. Am J Physiol Lung Cell Mol Physiol 2006, 291: L84-L90.

16. Lee JS, Kim HS, Seo SH: Genetic characterization and protective immunity of cold-adapted attenuated avian H9N2 influenza vaccine. Vaccine 2008, 26:6569-6576.

17. Wu R, Sui ZW, Zhang HB, Chen QJ, Liang WW, Yang KL, Xiong ZL, Liu ZW, Chen Z, et al: Characterization of a pathogenic H9N2 influenza A virus isolated from central China in 2007. Arch Virol 2008, 153:1549-1555.

18. Nagarajan S, Rajukumar K, Tosh C, Ramaswamy V, Purohit K, Saxena G, Behera P, Pattnaik B, Pradhan HK, et al: Isolation and pathotyping of H9N2 avian influenza viruses in Indian poultry. Vet Microbiol 2009, 133:154-163.

19. Peiris M, Yuen KY, Leung CW, Chan KH, Ip PL, Lai RW, Orr WK, Shortridge KF: Human infection with influenza H9N2. Lancet 1999, 354:916-917.

20. Lin YP, Shaw M, Gregory V, Cameron K, Lim W, Klimov A, Subbarao K, Guan Y, Krauss S, et al: Avian-to-human transmission of H9N2 subtype influenza A viruses: relationship between $\mathrm{H} 9 \mathrm{~N} 2$ and $\mathrm{H} 5 \mathrm{~N} 1$ human isolates. Proc Natl Acad Sci USA 2000, 97:9654-9658.

21. Saito T, Lim W, Suzuki T, Suzuki Y, Kida H, Nishimura SI, Tashiro M: Characterization of a human H9N2 influenza virus isolated in Hong Kong. Vaccine 2001, 20:125-133

22. Li KS, Xu KM, Peiris JS, Poon LL, Yu KZ, Yuen KY, Shortridge KF, Webster RG, Guan Y: Characterization of $\mathrm{H} 9$ subtype influenza viruses from the ducks of southern China: a candidate for the next influenza pandemic in humans? J Virol 2003, 77:6988-6994.

23. Brydon EW, Smith H, Sweet C: Influenza A virus-induced apoptosis in bronchiolar epithelial (NCl-H292) cells limits pro-inflammatory cytokine release. J Gen Virol 2003, 84:2389-2400.

24. Brydon EW, Morris SJ, Sweet C: Role of apoptosis and cytokines in influenza virus morbidity. FEMS Microbiol Rev 2005, 29:837-850.

25. Chan MC, Cheung CY, Chui WH, Tsao SW, Nicholls JM, Chan YO, Chan RW, Long HT, Poon LL, et al: Proinflammatory cytokine responses induced by influenza $A(\mathrm{H} 5 \mathrm{~N} 1)$ viruses in primary human alveolar and bronchial epithelial cells. Respir Res 2005, 6:135.

26. Julkunen I, Melen K, Nyqvist M, Pirhonen J, Sareneva T, Matikainen S: Inflammatory responses in influenza A virus infection. Vaccine 2000, 19(Suppl 1):S32-S37.

27. Buchweitz JP, Harkema JR, Kaminski NE: Time-dependent airway epithelial and inflammatory cell responses induced by influenza virus $A / P R / 8 / 34$ in C57BL/6 mice. Toxicol Pathol 2007, 35:424-435.
28. Hampton T: Virulence of 1918 influenza virus linked to inflammatory innate immune response. JAMA 2007, 297:580.

29. Baskin CR, Bielefeldt-Ohmann H, Tumpey TM, Sabourin PJ, Long JP, GarciaSastre A, Tolnay AE, Albrecht R, Pyles JA, et al: Early and sustained innate immune response defines pathology and death in nonhuman primates infected by highly pathogenic influenza virus. Proc Natl Acad Sci USA 2009, 106:3455-3460.

30. Tumpey TM, Lu X, Morken T, Zaki SR, Katz JM: Depletion of lymphocytes and diminished cytokine production in mice infected with a highly virulent influenza A (H5N1) virus isolated from humans. J Virol 2000 74:6105-6116.

31. Lipatov AS, Andreansky S, Webby RJ, Hulse DJ, Rehg JE, Krauss S, Perez DR, Doherty PC, Webster RG, et al: Pathogenesis of Hong Kong H5N1 influenza virus NS gene reassortants in mice: the role of cytokines and B- and T-cell responses. J Gen Virol 2005, 86:1121-1130.

32. Szretter K, Gangappa S, Lu X, Smith C, Shieh WJ, Zaki SR, Sambhara S, Tumpey TM, Katz JM: Role of host cytokine responses in the pathogenesis of avian H5N1 influenza viruses in mice. J Virol 2007, 81:2736-2744.

33. Matsukura S, Kokubu F, Noda H, Tokunaga H, Adachi M: Expression of IL-6, IL-8, and RANTES on human bronchial epithelial cells, NCl-H292, induced by influenza virus A. J Allergy Clin Immunol 1996, 98:1080-1087.

34. Seo SH, Webster RG: Tumor necrosis factor alpha exerts powerful antiinfluenza virus effects in lung epithelial cells. J Virol 2002, 76:1071-1076.

35. Cheung CY, Poon LL, Lau AS, Luk W, Lau YL, Shortridge KF, Gordon S, Guan Y, Peiris JS: Induction of proinflammatory cytokines in human macrophages by influenza $A$ (H5N1) viruses: a mechanism for the unusual severity of human disease? Lancet 2002, 360:1831-1837.

36. Sandbulte MR, Boon AC, Webby RJ, Riberdy JM: Analysis of cytokine secretion from human plasmacytoid dendritic cells infected with H5N1 or low-pathogenicity influenza viruses. Virology 2008, 381:22-28.

37. Hui KP, Lee SM, Cheung CY, Ng IH, Poon LL, Guan Y, Ip NY, Lau AS, Peiris JS: Induction of proinflammatory cytokines in primary human macrophages by influenza $A$ virus ( $\mathrm{H} 5 \mathrm{~N} 1)$ is selectively regulated by IFN regulatory factor 3 and p38 MAPK. J Immunol 2009, 182:1088-1098.

38. Adachi M, Matsukura S, Tokunaga H, Kokubu F: Expression of cytokines on human bronchial epithelial cells induced by influenza virus A. Int Arch Allergy Immunol 1997, 113:307-311.

39. Hao S, Baltimore D: The stability of mRNA influences the temporal order of the induction of genes encoding inflammatory molecules. Nat Immunol 2009, 10:281-288.

40. Carswell EA, Old L, Kassel RL, Green S, Fiore N, Williamson B: An endotoxin-induced serum factor that causes necrosis of tumors. Proc Natl Acad Sci USA 1975, 72:3666-3670.

41. Nain M, Hinder F, Gong JH, Schmidt A, Bender A, Sprenger H, Gemsa D: Tumor necrosis factor-alpha production of influenza $A$ virus-infected macrophages and potentiating effect of lipopolysaccharides. J Immunol 1990, 145:1921-1928

42. Choi AM, Knobil K, Otterbein SL, Eastman DA, Jacoby DB: Oxidant stress responses in influenza virus pneumonia: gene expression and transcription factor activation. Am J Physiol 1996, 271:L383-L391

43. Garcia-Sastre A, Durbin RK, Zheng H, Palese P, Gertner R, Levy DE, Durbin JE: The role of interferon in influenza virus tissue tropism. J Virol 1998, 72:8550-8558.

44. Maus U, von Grote K, Kuziel WA, Mack M, Miller EJ, Cihak J, Stangassinger M, Maus R, Schlondorff $D$, et al: The role of CC chemokine receptor 2 in alveolar monocyte and neutrophil immigration in intact mice. Am J Respir Crit Care Med 2002, 166:268-273.

45. Nelson PJ, Kim HT, Manning WC, Goralski TJ, Krensky AM: Genomic organization and transcriptional regulation of the RANTES chemokine gene. J Immunol 1993, 151:2601-2612.

46. Wright PF, Thompson J, Karzon DT: Differing virulence of $\mathrm{H} 1 \mathrm{~N} 1$ and $\mathrm{H} 3 \mathrm{~N} 2$ influenza strains. Am J Epidemiol 1980, 112(6):814-9.

47. Frank AL, Taber $L H$, Wells JM: Comparison of infection rats (sic) and severity of illness for influenza A subtypes H1N1 and H3N2. J Infect Dis 1985, 151(1):73-80

48. Willers $\mathrm{H}$, Höpken W: Epidemiology of influenza in Lower Saxony during the period 1968-1978 with particular emphasis on subtypes $A(H 3 N 2)$ and A(H1N1) in winter 1977-78. Med Microbiol Immunol 1979, 167(1):21-7.

49. Paglinawan R, Malipiero U, Schlapbach R, Frei K, Reith W, Fontana A: TGFbeta directs gene expression of activated microglia to an anti- 
inflammatory phenotype strongly focusing on chemokine genes and cell migratory genes. Glia 2003, 44:219-231.

50. Mayer AK, Bartz H, Fey F, Schmidt LM, Dalpke AH: Airway epithelial cells modify immune responses by inducing an anti-inflammatory microenvironment. Eur J Immunol 2008, 38:1689-1699.

51. Dybing JK, Schultz-Cherry S, Swayne DE, Suarez DL, Perdue ML: Distinct pathogenesis of hong kong-origin $\mathrm{H} 5 \mathrm{~N} 1$ viruses in mice compared to that of other highly pathogenic H5 avian influenza viruses. J Virol 2000, 74:1443-1450

52. Cauthen AN, Swayne DE, Sekellick MJ, Marcus PI, Suarez DL: Amelioration of influenza virus pathogenesis in chickens attributed to the enhanced interferon-inducing capacity of a virus with a truncated NS1 gene. J Virol 2007, 81:1838-1847.

53. Pei Y, Swinton J, Ojkic D, Sharif S: Genetic characterization of two low pathogenic avian influenza virus H5N1 isolates from Ontario, Canada. Virus Genes 2009, 38:149-154.

54. Raz E: Organ-specific regulation of innate immunity. Nat Immunol 2007, 8:3-4.

55. Pinto RA, Arredondo SM, Bono MR, Gaggero AA, Diaz PV: T helper $1 / T$ helper 2 cytokine imbalance in respiratory syncytial virus infection is associated with increased endogenous plasma cortisol. Pediatrics 2006, 117:e878-e886.

56. Hatada E, Hasegawa M, Mukaigawa J, Shimizu K, Fukuda R: Control of influenza virus gene expression: quantitative analysis of each viral RNA species in infected cells. J Biochem 1989, 105:537-546.

57. Ohshima K, Hamasaki M, Makimoto Y, Yoneda S, Fujii A, Takamatsu Y, Nakashima M, Watanabe T, Kawahara K, et al: Differential chemokine, chemokine receptor, cytokine and cytokine receptor expression in pulmonary adenocarcinoma: diffuse down-regulation is associated with immune evasion and brain metastasis. Int J Oncol 2003, 23:965-973.

58. O'Gorman GM, Park SD, Hill EW, Meade KG, Mitchell LC, Agaba M, Gibson JP, Hanotte O, Naessens J, et al: Cytokine mRNA profiling of peripheral blood mononuclear cells from trypanotolerant and trypanosusceptible cattle infected with Trypanosoma congolense. Physiol Genomics 2006, 28:53-61.

\section{doi:10.1186/1743-422X-7-344}

Cite this article as: Lam et al:: Profiles of cytokine and chemokine gene expression in human pulmonary epithelial cells induced by human and avian influenza viruses. Virology Journal 2010 7:344.

\section{Submit your next manuscript to BioMed Central and take full advantage of:}

- Convenient online submission

- Thorough peer review

- No space constraints or color figure charges

- Immediate publication on acceptance

- Inclusion in PubMed, CAS, Scopus and Google Scholar

- Research which is freely available for redistribution

Submit your manuscript at www.biomedcentral.com/submit
Biomed Central 